\title{
Turizmde Arıcılığın Kullanımına Keşifsel Bir Yolculuk*
}

An Exploratory Journey to the Use of Beekeeping in Tourism

\author{
Belma SUNA** \\ * Dr. Öğr. Üyesi, Gaziantep Üniversitesi, Turizm ve Otelcilik Meslek Yüksekokulu, Burç Yolu Üzeri, 27100, Şahinbey, Gaziantep. \\ E-posta: suna@gantep.edu.tr \\ ORCID: 0000-0003-0710-2678
}

\section{MAKALE BILGILERI \\ Makale işlem bilgileri: \\ Gönderilme tarihi: 12 Temmuz 2019 \\ Düzeltme: 21 Ağustos 2019 \\ Düzeltme: 19 Eylül 2019 \\ Kabul: 24 Eylül 2019 \\ Anahtar sözcükler: Kırsal turizm, Arculik turizmi, Api turizm, Gaziantep.}

\section{ARTICLE INFO}

Article history:

Submitted: 12 July 2019

Resubmitted: 21 August 2019

Resubmitted: 19 September 2019

Accepted: 24 September 2019

Key words: Rural tourism, Beekeeping Tourism, Api tourism, Gaziantep.

\begin{abstract}
ÖZ
Kırsal turizmin bölge kalkınmasında etkili olduğu bilinmektedir. Kırsal turizm denince akla çoğu zaman tarım turizmi, agro turizm veya çiftlik turizmi gelmektedir. Türkiye, sahip olduğu doğal zenginliği nedeniyle kırsal turizm kapsamında ele alınabilecek pek çok unsura sahiptir. Arıcılık turizmi ise çevre koruma bilincinin yerleștiği ülkelerde hem bölgesel kalkınmaya olumlu yönde etki eden hem de arı yetiștiriciliği yapan çiftçilere ek gelir sağlayan bir turizm türüdür. Araştırmanın amacı, Gaziantep'teki arı yetiştiricilerinin arıcılık turizmine bakış açılarını anlamak ve arıcılık turizmi konusunda farkındalık oluşturmaktır. Verilerin elde edilmesinde derinlemesine yarı yapılandırılmıș mülakat tekniği kullanılmıștır. Görüșmeler, Ekim-Aralık 2018 tarihleri arasında 11 arı yetiştiricisiyle gerçekleştirilmiş olup demografik sorular ve arıcılık turizmi, api terapi ve arıcılık turizminin geleceğine dair toplam yedi soru sorulmuştur. MAXQDA Nitel Araştırma Programı kullanılarak gerçekleștirilen analizler sonucunda, arıcıların büyük çoğunluğunun arıcılık turizmini duymadıkları tespit edilmiștir. Bununla birlikte Gaziantep ve Türkiye'de yaygınlaştırılacak olan arıcılık turizminin geleceğine dair olumlu yönde bakış açılarına sahip oldukları anlaşılmıştır.
\end{abstract}

\section{ABSTRACT}

It is known that rural tourism is effective in regional development. When it comes to rural tourism, agricultural tourism, agrotourism or farm tourism are often the most important ones. because of the natural wealth that Turkey has covered rural tourism has many elements to be addressed. Bee tourism, on the other hand, is a type of tourism that positively affects regional development and provides additional income to bee farmers in the countries where environmental protection awareness is settled. The aim of the research is to understand bee growers' perspectives in Gaziantep, on bee tourism and to raise awareness of bee tourism. In-depth semi-structured interview technique was used to obtain the data. The interviews were conducted with 11 beekeepers between October-December 2018 and seven questions were asked about demographic questions and the future of bee tourism, and bee tourism. As a result of the analyses performed using the MAXQDA Qualitative Research Program; The majority of beekeepers do not hear bee tourism. However, the bees Gaziantep and tourism, which will be expanded in Turkey have understood that they have a positive perspective on the future.

\section{Giriş}

Kırsal turizm kapsamındaki faaliyetler, kentleşme sürecinin ortaya çıkmasıyla hayat bulmuştur. Şehir yaşamının insanlar üzerindeki stres ve kaygiyı tetikleyici etkisi, sakin ve huzur dolu ortamlara olan gereksinimi arttırmıştır. Çoğunlukla iç

\footnotetext{
*Bu makale, 13-16 Haziran 2019 tarihleri arasında Bodrum'da düzenlenen Ulusal Kırsal Turizm Kongresinde bildiri olarak sunulan ve bildiri kitabında yayınlanan "Arı Turizmine Keşifsel Bir Yolculuk" başlıklı bildirinin geliştirilmiş halidir.
}

turizmin faaliyet alanında değerlendirilen kırsal turizm son yıllarda ulaşım olanaklarının ve iletişim teknolojilerinin de gelişmesiyle birlikte uluslararası bir boyut kazanmış ve son zamanlarda hem yerli hem de yabancı birçok araştırmaya konu olmuştur (Gartner 2005; Bhadauria ve Rastogi 2012; Ayazlar ve Ayazlar 2015; Garau 2015; Özçatalbaş 2017; Kantar ve Svržnjak 2017). Kırsal turizm kavramını sürdürülebilir turizm kapsamında ele alan araştırmaların yanı sıra (Bhadauria ve Rastogi 2012; Blinnikka vd. 2014; Garan 2015) 
kırsal kalkınma (Ün vd. 2012; Drăgulănescu ve Druțu 2012; Civeler vd. 2014) konusu içinde ele alan çalışmalar da bulunmaktadır. Kırsal turizm bazen kavramsal bir çerçeveden açıklanmış olup (Heneghan 2009; Aydın 2012; Ayazlar ve Ayazlar 2015; Doğan ve Özaslan 2017), bazen de alternatif turizm türlerinden biri (Esengün vd. 2001; Pamukçu Aydoğdu ve Gemici 2015: 523; Neumeier ve Pollermann 2014) olarak ele alınmıştır.

Arıcılık turizmi (Api Turizm) kavramı ise Türkiye'de yeni ortaya çıkan bir turizm türü olup, temelinde çevre bilincini barındıran ve beraberinde bu bilinci yeni nesillere aktarmayı amaçlayan bir yapıdadır (Wos 2014; Korosec 2016; Suna 2018). Bu turizm türü, arı yetiştiricilerinin çalışmalarıyla paralellik göstereceğinden hem sürdürülebilir turizm anlayışına katkı sağlayacak hem de ekonomik kalkınmaya doğrudan etki edecektir. Ancak Almanya, İngiltere, Misır, Polonya, Slovenya, Polonya ve Şili gibi ülkelerde yaygin olan api turizm (Korosec 2014; Shiffler 2014; Wos 2014; Housam ve Abou Shaara 2015; Pantoja vd. 2017) Türkiye'de yasal bir zemine oturtulamamıştır. Bu araştırmanın amacı, Gaziantep'te faaliyet gösteren arı yetiştiricilerinin arıcılık turizmine bakış açılarını anlamak ve arıcılık turizmi konusunda bir farkındalık oluşturmaktır. Bu araştırma, arıcılık turizmini arı yetiştiricilerinin bakış açısından değerlendirdiği için yazında var olan diğer araştırmalardan farklılık arz etmektedir. Arıcılık turizminin boyutları ve kapsamının doğru bir zeminde yapılandırılmasını sağlama ihtimali olması araştırmayı önemli kılan diğer bir sebeptir. Bu doğrultuda geliştirilecek arıcılık turizmi faaliyetlerinin daha bilinçli yapılandırılacağı düşünülmektedir.

\section{ALANYAZIN}

Kırsal alanlar, doğal ve kültürel yapılarıyla, özellikle büyük şehirlerde yaşayan insanların huzur bulmak amacıyla kaçış noktası haline gelmeye başlamıştır. Şehir halkı, eskiden kırsal alanlara, rekreasyon amaçlı veya akraba ziyaretleri için giderken, doğal yaşam ve organik tarım kavramlarının popüler hale gelmesiyle birlikte bir yaşam biçimi haline gelmiştir. Bu amaçlarla başlayan süreç kısaca, "kırsal alanlarda gerçekleştirilen turizm türü" (Soykan 1999: 68; Ongun vd. 2016: 76) haline gelmiştir. Cabrini'ye (2004) göre kırsal turizmin bileşenleri merkezde kırsal turizm toplumu olmak üzere, kırsal alanlar, kırsal yaşam, kırsal miras ve kırsal ile beş bileşenden oluşmaktadır. Bu yapıda kırsal alanlar başlığını; dağlar, göller, nehirler, ormanlar ve doğa manzaraları oluştururken, kırsal yaşam bileşenini; el sanatla$\mathrm{r} 1$, yerel etkinlikler, beslenme, agro turizm, geleneksel müzik oluşturmaktadır. Ayrıca yerel mimari, tarihi miras, yöresel kafe ve dini unsurlar kırsal mirası oluştururken, bisiklete binme, balık tutma, at binme, avcılık ve yürüyüş gibi faaliyetler kırsal etkinlikler bileşenini oluşturmaktadır (Nair vd. 2015; Doğan ve Özaslan 2017: 62).

Kırsal turizmin bileşenlerinden biri olan kırsal alanlar daima tarımla ilişkilendirilmiştir ve dünyadaki toprağın büyük bölümünü oluşturmaktadır. Kırsal alan kavramı, turizm endüstrisine göre değerlendirildiğinde; "deniz turizmi merkezleri dışında kalan, kentsel yerleşimlerden uzak, kırsala özgü hayatın korunduğu, kırsal hayatla ilgili çeşitli aktivitelerin gerçekleştirildiği yerler" olarak tanımlanabilir. Kırsal turizm, gelişmekte olan bir turizm alanı olup, katılımcısı da gün geçtikçe artmaktadır (Heneghan 2002:72).

Kırsal turizm, günümüzde tarımsal faaliyetlerin yoğun olduğu yörelerde gelişen bir turizm çeşidi olup, yeşil turizm, çiftlik turizmi, köy turizmi, yayla turizmi, tarım turizmi gibi isimler alabilmektedir. Katılımcılara, sosyal ve psikolojik sorunlarının çözümünde yarar sağlarken, gelir düzeyi diğer sektörlere göre düşük olan tarım üreticisine ek bir gelir sağlamaktadır (Olalı ve Timur 1988). Ayrica diğer turizm türleriyle kolay bir şekilde entegre edilebilmesi, her mevsimde tercih edilebilir olması, bu turizm türünü seçen turistlerin farklı bir profil sergilemesi (Karacan vd. 2016: 4) açısından da büyük önem arz etmektedir. Kırsal turizmin bu çok boyutlu ve uyumlu yapısı henüz yasal bir zeminde yeri olmayan arıcllık turizmi ile birleştirilebilme imkânını ortaya çıkarmıştır.

Api sözcüğ̈u, Latince kökenli olup "Apis mellifera"dan türetilmiştir (Abou Shaara 2014). Arıcılık turizmi, arı yetiştiricilerine ve api-terapi tedavi uzmanlarına niş turizm pazarındaki ko- 
numlarını geliştirmek ve sağlamlaştırmak için büyük firsatlar sunmaktadır (Korosec 2016). Ar1cllık turizmi; arının ekolojik dengedeki yerini ve önemini bilme fikri ile hayat bulan, çevre koruma bilinci ve bu konuda insanlara düşen sorumluluk bilinci ile devam eden bir süreçtir. Turizm endüstrisinde dünya üzerinde en az on yıldır var olan ancak Türkiye'de yeni bir fikir olan arıcılık turizmi, aslında yeşil ekonominin önemli bir bileşeni olarak ortaya çıkmış ve geliştirilmiştir (Korosec 2016). Geniş bir çerçeve ile api turizm; arı kültürü ve hayranlığıyla seyahat eden özel bir kitlenin, bu kültürü daha iyi kavramak, sağlıklı yaşamının devamını sağlamak veya arı ve arıdan elde edilen ürünlerle tedavi olmak amaciyla arıların varlığını sürdürdüğü doğal ortamına gitmesi sonucu orada konakladığı süreçte ortaya çıan faaliyetler bütünüdür (Suna 2018: 48).

Yabancı yazın tarandığında Wos'un (2014) yapmış olduğu çalışmada Dünya'da Slovenya, Polonya, Çek Cumhuriyeti, Almanya, Misır gibi ülkelerdeki arıcılık turizmi destinasyonlarını ziyaret eden turistlerle çalıştığ 1 görülmektedir. $\mathrm{Bu}$ destinasyonlarda; arıdan elde edilen şifalı ürünlerin satın alınması, arı müzelerinin ziyaret edilmesi, arının ekolojik sistemdeki önemine dikkat çekilen sunumların yapılması gibi faaliyetlerin gerçekleştirildiğini tespit etmiştir. Ayrıca lise çağ 1 gençler ve ana okulu öğrencilerinin en fazla arıc1lik turizmi merkezlerini ziyaret eden grup olduğu ortaya çıkarılmıştır (Wos 2014). Korosec, arıcılık turizmini çoğunlukla kavramsal açıdan ele almış olup, hem Slovenya'yı kapsayan araştırmalar yapmış $(2014$; 2015; 2017) hem de Türkiye'de gerçekleştirilen Muğla Çam Balı Kongresi'ne (2016) katkı sağlamıştır. Korosec, çalışmalarında arıcılık turizminin yeri ve önemine vurgu yapmıştır. Shiffler 2014 yılında yapmış olduğu araştırmada Api turizmin Şili'ye daha fazla değer kattığını ortaya koymuştur. Pantoja vd. ise (2017) çoklu seçim kriterleri kullanmak suretiyle Şili'de api turizm merkezi kurmak için uygun olan noktaları belirlemek suretiyle haritalama yapmışlardır. Bahar ve Yılmaz, Muğla'da arıcılık turizmi ve uygulanabilirliğini kavramsal açıdan ele almışlardır. Suna (2018a), arıcılık turizmini alternatif turizm türü olarak ele almış ve (2018b) arıcılık turizmini sağlık turizmi kapsamında SWOT analizini yaparak değerlendirmiştir. Özetle, arıcılık turizmini konu alan araştırmalar, çoğunlukla kavramsal açıdan çalışılmıştır. Araştırma yazına yeni bir bakış açısı kazandırması, arıcılık turizmi ile ilgili farkındalık oluşturması ve arıcılık turizmi kavramını oluşturan temelleri ortaya çıkaracağı için önem arz etmektedir. Araştırmanın temel amacı, Gaziantep'te faaliyet gösteren arıcıların arıcılık turizmine bakış açılarını anlamaktır. Araştırmanın bir diğer amacı ise arı yetiştiricilerinin arıc1lık turizmi hakkında fikir sahibi olmalarını sağlamaktır.

\section{YÖNTEM}

Gaziantep'te faaliyet gösteren arı yetiştiricilerinin arıcılık turizmine bakış açılarını anlamak ve arıcılık turizmi ile ilgili farkındalık oluşturmak amacıyla yapılan bu çalışmada, nitel araştırma desenlerinden durum çalışması deseni kullanılmıştır. Durum çalışması araştırmacının gerçek yaşam, güncel sınırlı bir sistem ya da belli bir zaman içerisindeki çoklu bilgi kaynakları (gözlem, mülakat, görsel-işitsel materyaller ve dokümanlar) aracılığıyla detaylı ve derinlemesine bilgi topladığı, bir durum betimlemesi ya da durum temaları ortaya koyduğu bir yaklaşımdır (Creswell 2016: 97). Bu doğrultuda toplanan verilere içerik analizi uygulanmıştır.

Çalışmanın problem cümlesi şöyle ifade edilmiştir; Gaziantep'teki arı yetiştiricilerine göre arıcılık turizmi ne anlam ifade etmektedir ve ar1cılık turizmi ne gibi katkılar sağlar? Hazırlanan soruların sorulmasından önce arı yetiştiricilerine arıcılık turizmi ile ilgili kısa bir açıklama verilmiştir. Birinci bölümde arıcıların demografik özelliklerini ortaya çıkarmaya yönelik 11 soru sorulmuştur. İkinci bölümde ise arıcılık turizmini ve arıcılık turizmini oluşturan unsurları arıc1ların kendi cümleleriyle ifade etmelerine yönelik yedi adet yarı yapılandırılmış mülakat soruları bulunmaktadır. Yapılan yüz yüze görüşmeler sırasında sorular katılımcılara yöneltilmiş, gerektiğinde "Biraz daha açar mısınız", "Başka şekilde nasıl ifade edebilirsiniz", "Örnek verir misiniz" gibi sorularla elde edilen veriler genişletilerek desteklenmiştir. Bu sorular aşağıdaki gibidir; 
1. Gaziantep yöresinde arıcılığın geleceğine bakış açınız nedir?

2. Arı ürünleri ile tedavi yöntemi yani Apiterapi hakkında ne düşünüyorsunuz?

3. Hastalıklarının tedavisi için kişilere arı ürünlerini kullanmalarını tavsiye ettiniz mi? Ne gibi tavsiyelerde bulundunuz?

4. Arıcılık turizmi hakkında ne düşünüyorsunuz? Sizce talep olur mu?

5. Arıcılık turizmi sizce ne gibi katkılar sağlar?

6. Arıcılık turizminin ilinizde yaygınlaşması için yapılması gerekenler sizce nelerdir?

7. Katkı sağlamak açısından eklemek istediğiniz bir şey var mıdır?

Araştırmanın katılımcılarını belirlemek için nitel araştırma yöntemlerinden amaçlı örneklem stratejisinden yararlanılmıştır. Kartopu veya zincir örnekleme, çalışmada yer alan ölçütlere uyan katılımcılara kolayca yer vermeyi içerir. Mevcut katılımcılarla görüşülürken onlara yeni katılımcıları da kastederek sorular sormayı gerektirdiğinden kartopunu büyütür ve konuya hâkim kişilere ulaşmayı kolaylaştırır (Berg ve Lune 2015: 71; Merriam 2015: 78). Arıcılık turizmi Gaziantep'te henüz yaygin olmayan bir turizm türü olduğundan konu hakkında en çok bilgi sahibi olan kişilere ulaşabilmek amaciyla kartopu veya zincirleme örneklem türü kullanılmıştır. Bu kapsamda görüşülebilecek ilk kişinin kim olacağ 1 Gaziantep Arıcılar Birliği Başkanı'na sorularak belirlenmiştir. Daha sonra ise görüşülen kişilerden bu konuda bilgi sahibi olabilecek diğer arıcılar sorulmuş, aynı isimler tekrar etmeye başladığında katılımCı bulma süreci durdurulmuştur (Merriam 2015: 78).

Mülakatlar, Ekim 2018-Şubat 2019 tarihleri arasında, katılımcılardan randevu alınarak gerçekleştirilmiştir. Bu süreç sonucunda, Gaziantep Arıcılar Birliği'ne kayıtlı 11 arı yetiştiricisi ile görüşülmüştür. Görüşme sırasında katılımcının izni alınarak ses kaydı yapılmıştır. Alınan ses kayıtları araştırmayı yürüten yazar tarafından deşifre edilmiştir. Elde edilen 21 sayfalık deşifre metinleri MAXQDA Nitel Veri Analiz Programı kullanılarak içerik analizine tabi tutulmuştur.
İçerik analizinde mekânların, stillerin, imajların, anlamların ve nüansların anahtar sözcük olarak yer aldığı iç görü elde edilmeye çalışılır. İçerik analizi aynı zamanda verilerin kodlanmasını ve kategorilerin oluşturulmasını da sağlayan dört aşamalı bir süreçtir (Merriam 2015: 196). Bu aşamalarda öncelikle katılımcıların soru formlarında arıcllık turizmi ve bu turizm türünü oluşturan unsurlarına dair kullandıkları sözcükler ve cümleler detaylı bir şekilde incelenmiştir. Bu incelemeler sonucunda çözümlenerek ifade ettikleri anlamlara göre kodlamıştır. Bu kodlar yardımıyla veriler yazından elde edilen kavramsal çerçeve ve kodlama şemasıyla uyumlu olarak ilgili ana ve alt temalara göre sınıflandırılmıştır.

Arıcılık turizmine dair elde edilen veriler birbirinden bağımsız iki farklı kodlayıcı tarafından kodlanmıştır. Bu kodlama araştırmacının beklenti ve sorularından habersiz olarak başka kişiler tarafından "gizli/birbirinden habersiz (blind)" biçiminde yapılmış olup, verilerin analizi ve kodlanması için onlar da MAXQDA programını kullanmışlardır (Creswell 2016: 253). Kodlayıcılar arasında yüzde 75 oranında benzerlik olduğunun ortaya çıkarılması kodlama güvenirliğinin yeterli düzeyde olduğunu göstermektedir (Miles ve Huberman 1994). Böylece temaların araştırma amaçlarına uygun olarak ortaya çıkarıldı ğ ve kodlayıcılar arasındaki uyumun güvenirliliği sağlayacak düzeyde olduğu anlaşılmıştır.

\section{BULGULAR VE TARTIŞMA}

Araştırmanın bu bölümünde demografik verilere ve arıcılık turizmine dair bulgulara yer verilmiştir.

\section{Demografik Verilere ilişkin Bulgular}

Araştırmada görüşülen tüm arı yetiştiricileri erkek olup bu arıcılar gelir durumlarını "orta düzey" olarak ifade etmişlerdir. Katılımcıların çok büyük kısmı mesleğini "arıcılık" olarak ifade etmiş olup, arıcılardan sekizi (A1, A2, A4, A5, A6, A7, A9, A11) için arıcılık bir "geçim kaynağı" olarak görülürken, üçü (A3, A8, A10) için "hobi" mahiyeti taşımaktadır. Araştırmaya katılan arıc1lardan meslekte en az faaliyet gösteren arıcının (A6) sekiz yıldır bu alanda çalıştığı anlaşılırken, en fazla çalışan arıcının (A9) ise bu işi "40 yıldan 
fazla" bir süredir yaptığı anlaşılmıştır. Araştırmaya katılan kişilerden altı arıcı (A3, A5, A6, A8, A9, A10), arıc1lık mesleğini "ek iş" olarak sürdürürken, beş arıcı (A1, A2, A4, A7, A11) "asıl iş" yani bu işi bir "geçim kaynağı" olarak yapmaktadır. Ek iş olarak arıcılık yapan katılımcıların çoğu arıcılık ile birlikte çiftçilik de yapmaktadır. Ayrica altı arıcı (A2, A4, A6, A7, A9, A10) arıcılik mesleğini sonradan yapmaya başlamışken, beş arıcinın (A1, A3, A5, A8, A11) dedesinden ve ailesinden öğrenerek bu işi yaptığ bulgular arasındadır. Katılımcıların hepsi "bal" üretimi yaparken, büyük çoğunluğunun bal, propolis ve poleni birlikte ürettikleri anlaşılmıştır. Bunun yanı sıra, arı zehri, arı sütü, bal mumu üreten arıcılar da araştırmaya katılımcı olmuştur. Bu kapsamda dikkat çeken nokta ise arıcılardan sadece ikisinin "arı üretimi" yaparak, "ana arı" satışı yapmasıdır.

\section{Arıcılık Turizmi ve Unsurlarına Dair Bulgular}

Araştırmanın bu bölümünde arıcılık turizmine dair elde edilen bulgulara yer verilmiştir. Bu başlık altında ele alınan bulgular üç tema ve dokuz alt temalardan oluşmaktadır.

\section{Tema 1: Arı Ürünleri ile Tedavi}

Geleneksel ve tamamlayıcı tıp alanında 15 Ekim 2014 tarihinde T.C. Sağlık Bakanlığı tarafından çıkarılan yönetmelikle resmileştirilen apiterapi (arı ürünleriyle tedavi) yöntemi, Türkiye'de yasal bir zemin kazanmış olup, arıcılık sektöründe arı ürünlerinin üretimi, standartlaştırılması ve üretimin artırılması yönünde çalışmalar devam etmektedir (Resmî Gazete 2014). Bu yasal çerçevenin arı yetiştiricileri tarafından ne oranda bilindiği aslında çok önemlidir.

Katılımcilardan A2, A6, A7 ve A11 nolu arıc1ların apiterapi tedavi kavramını tam olarak bil-

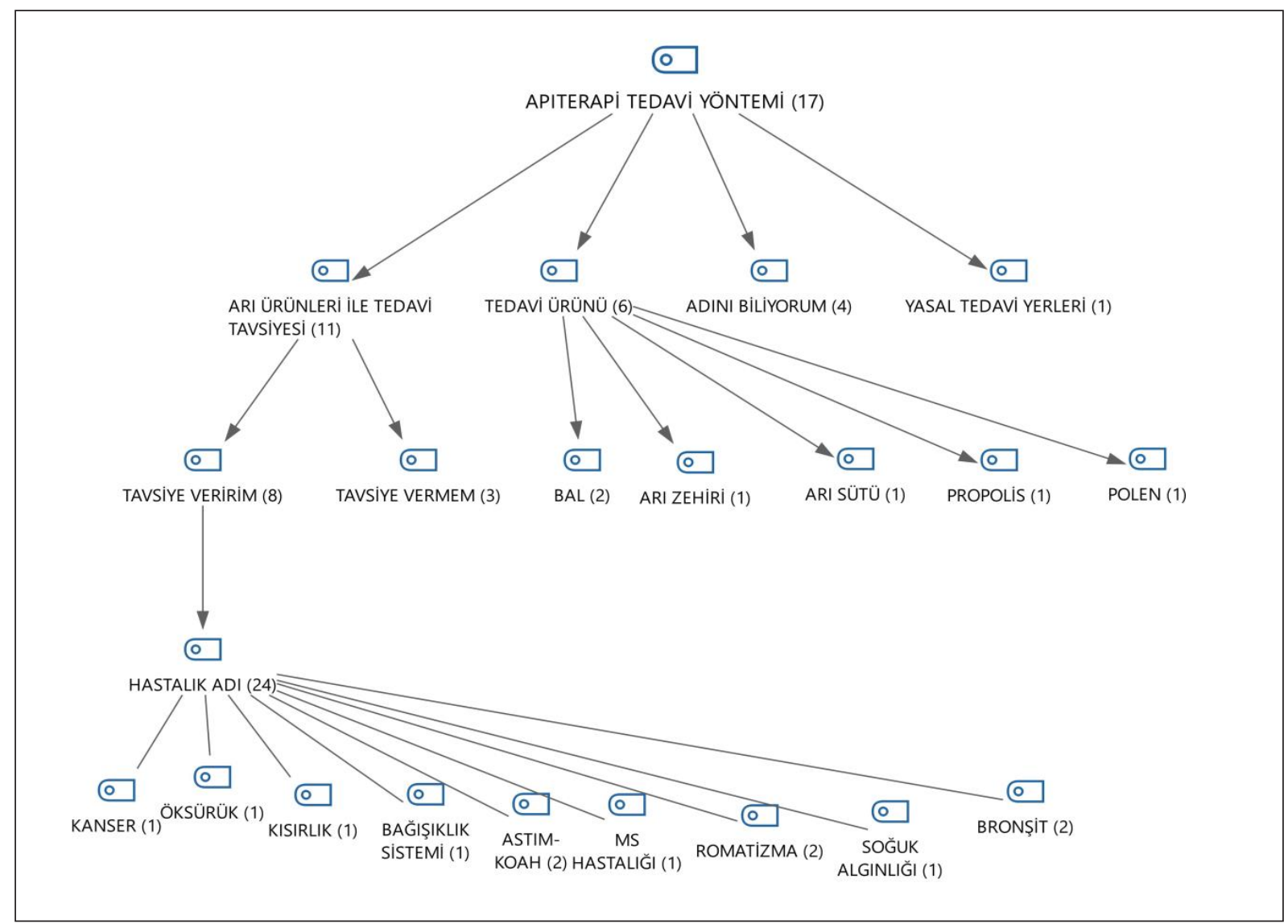

Şekil 1. Api Terapi Tedavi Yöntemi Hiyerarşik Kod-Alt Kod Modeli 
dikleri, bununla birlikte tüm arıcıların arı ürünleri ile tedavi yapıldığını bildikleri anlaşılmıştır. Katılımcılar bronşit, grip, soğuk algınlığı, romatizmal ağrılar, kanser, nefes darlığı, astım, koah gibi hastalıklara ve kısırlığa iyi geldiğini ifade etmişlerdir. Beraberinde arıcılardan büyük bir kisminin A1, A2, A5, A6, A7, A8, A9, A11 kendilerinden ürün almak için gelen kişilere ve kendi aile bireylerine tedavi tavsiyesinde bulundukları elde edilen bulgular arasında yer almaktadır. Bir katılımcının öne çıkan ifadesi şöyledir:

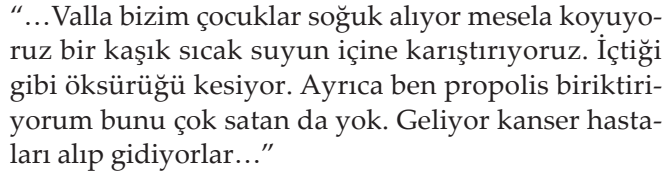

“...Valla bizim çocuklar soğuk alıyor mesela koyuyoruz bir kaşık sıcak suyun içine karıştırıyoruz. İçtiği gibi öksürügü kesiyor. Ayrıca ben propolis biriktiriyorum bunu çok satan da yok. Geliyor kanser hastaları alıp gidiyorlar..."

Apiterapi yani arı ürünleri ile tedavi yapılan resmi merkezlerin arıcılar tarafından çoğunlukla bilinmediği tespit edilmiştir. Yalnızca A11 numaralı arıcı bu konu ile ilgili doğru ve net bir bilgiye sahip olduğunu ifade etmiş olup, konuşması aşağıdaki gibidir;

“...Alternatif tıpçılar bu işi yapıyor. Medipol Üniver-
sitesi, Sağllk Bakanlığ1 çalışanlarına Apiterapi'yle il-
gili seminerler düzenleyerek kurs veriyor...”

\section{Tema 2: Arıcılık Turizmi Hakkında Görüşler}

Araştırmanın bu kısmında Tema 2 başlıklı bulgulara yer verilmiştir. Bu kapsamda elde edilen bulgulardan birincisi arı yetiştiricilerinin arıcıllk turizmi ile ilgili bilgi düzeyinin ortaya konulmasıdır. Arıcılık turizminin uygulanabilirliğine ve talebe yönelik bulgular yine bu başlık altına ele alınmıştır.

\section{Tema 2-1 Arncllk Turizmine Dair Genel Görüşler}

Araştırmaya katılan arı yetiştiricilerinden A1, A3, A4, A5, A8 ve A10 kodlu arıcılar bu kavramı daha önce hiç duymadıklarını belirtmişlerdir. A7 ve A11 ise böyle bir turizm türünü bildiklerini söylerken, A2, A6 ve A9 böyle bir turizm türünün bir gereklilik olduğunu veya hayata geçirilirse uygun olacağını ifade etmişlerdir.

Tema 2-2 Arıcılık Turizminin Uygulanabilirliğine Yönelik Bulgular

Arıcılık turizminin Gaziantep'te ve Türkiye'de uygulanabilirliğine dair görüşleri sorulduğunda arı yetiştiricilerinin büyük çoğunluğu böyle bir uygulamanın yararlı olacağı görüşüne sahiptir. Katılımcılardan A4 ve A8 kodlu arı yetiştiricisi bu turizm türünün Gaziantep'te uygulanmasının mümkün olamayacağ 1 görüşündedir. Olumlu açıdan yaklaşan A11 ve A2 kodlu katılımcıların konuya dair görüşleri şöyledir:

\begin{abstract}
A11: “...Gaziantep'te bu iş kesinlikle yapılır. Gaziantep büyük bir şehir. Api turizminin tanıtımı güzel bir şekilde yapılırsa daha başarılı olunacağını ve kesinlikle insanların yarar göreceklerini düşünüyorum..."

A2: “...Api turizminin Türkiye'de hayata geçirilmesi de çok kolay olur. Türkiye'de biliyorsunuz tek mevsim yaşanmıyor, yani günde dört mevsim yaşanabilecek bir ülke. Akdeniz sahilinde bahar iken Doğu'da işte karlar yerde, dolayısıyla bu yıl içerisinde sürekli olarak hem arıların yaşam ve sağlıklı olması hem de bu turizminde bölgesel olaraktan ayrı ayrı zamanlarda yapılabilmesi için ülkemiz çok uygun..."
\end{abstract}

Olumsuz bakış açısına sahip olan A4 kodlu katılımcının ifadesi şöyledir:

\begin{abstract}
“... Uygulanabileceğini sanmıyorum. Çünkü ben arılarımı gezdiriyorum. Bir yerde benim en fazla kalacağım süre maksimum bir aydır. Sonra ben arılarımın yerini değiştiririm. Ĕ̆er ben bulunduğum yere turizmin gelmesini beklersem gereken verimi alamam..."
\end{abstract}

Tema 2-3 Arıcılık Turizmine Talebe Yönelik Bulgular

Gaziantep'te böyle bir turizm türüne talebin nasıl olacağına dair görüşler analiz edildiğinde büyük bir kısmının yine olumlu bakış açısına sahip olduğu görülmüştür. Bu başlık altında elde edilen dikkat çekici bulgu ise A10 kodlu arıcıya aittir.

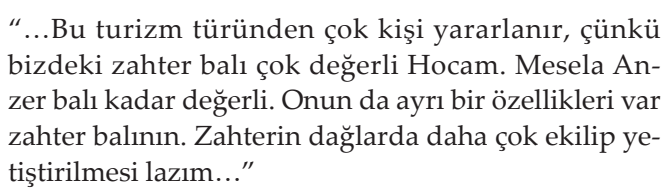
zer balı kadar değerli. Onun da ayrı bir özellikleri var zahter balının. Zahterin dağlarda daha çok ekilip yetiştirilmesi lazım..."

\section{Tema 2-4 Arıcılık Turizminin Katkılarına Yönelik Bulgular}

Araştırmanın bu bölümünde arıcılık turizmi geliştirilirse sağlayacağ 1 katkılar değerlendirilmiştir. Araştırmaya katılan arı yetiştiricilerinden sekiz arıc1 (A1, A2, A3, A5, A8, A9, A10 ve A11) arıcılık turizminin kendilerine katkı sağlayabileceğini, dört tanesi topluma (A1, A7, A10 ve A11) katkı sağlayabileceğini, dört tanesi çevreye (A7, A8, A10 ve A11) katkı sağlayabileceğini ve son 
olarak üçü bölgeye (A2, A5 ve A11) katkı sağlayabileceğini ifade etmiştir. Arı yetiştiricileri cevaplarında bu seçeneklerin hepsini, birini ya da birkaçını aynı anda kullanmışlardır. Katılımcılardan A4 ve A6 ise konu hakkında bilgi sahibi olmadıkları için görüş bildirmemişlerdir.

\section{Tema 3: Arıcılık Turizmini Geliştirmek}

Araştırmanın bu bölünde arıcılık turizmini geliştirmek için yapılması gerekenlere, böyle bir turizm türü için görevlendirilebilecek kuruluşlara, arıcılık turizminin sağlayabileceği potansiyel katkılara, arıcılık turizminin boyutlarına ve karşılaşılabilecek sorunlara yönelik bulgulara yer verilmiştir.

Tema 3-1 Arıcılık Turizmini Geliştirmek İçin Yapılması Gerekenler

Gaziantep'te arıcılık turizminin nasıl geliştirilebileceğine dair yöneltilen sorulara verilen cevaplar değerlendirildiğinde, A1, A2, A4, A5, A7 ve A11 nolu katılımcılar görüş bildirmişlerdir.
Bu görüşler değerlendirildiğinde "Arıcılık turizmin tanıtım faaliyetlerine başlanması" (A2, A5 ve A11) en çok tekrarlanan öneri olmuştur. Bununla birlikte api terapi tedavilerinin profesyonelce uygulanması (A2, A11) ve arıcıların bilinçlendirilmesi (A1, A4) gerekliliği iki kez; Arı Müzesi açılması (A2), İl Tarım Müdürlüğünde toplantı (A1) ve Arı Bahçesi'nin kurulması (A7) görüşlerinin ise sadece birer kez ifade edildiği anlaşılmıştır.

Tema 3-2 Arıcılık Turizmi İçin Görevli Olabilecek Kuruluşlar

Araştırmanın bu bölümünde arıcılık turizminin yaygınlaştırılması için yapılması gereken çalışmalara ve görev düşen kuruluşlara dair bulgulara yer verilmiştir.

Bu kısımda arı yetiştiricileri arıcılık turizmini geliştirebilmek için görevli olduğunu düşündükleri kurumların isimleri Tablo 1'deki gibidir. Tabloda en sik tekrarlanan "tanitım faaliyetlerine başlanması" fikri ile en fazla ilişkili olduğu anlaşılan kurumların Büyükşehir Belediyesi (A2, A3,

Tablo 1. Arıcılık Turizminin Yaygınlaştırılması için Yapılması Gerekenler ve Görevli Kurumlar Kod İlişkileri Tablosu

\begin{tabular}{|c|c|c|c|c|c|c|c|c|c|c|}
\hline & \multirow[b]{2}{*}{ Kod Sistemi } & \multicolumn{9}{|c|}{ Arıcılık Turizmini Yaygınlaştırmak Için Görevli Kurumlar } \\
\hline & & $\begin{array}{c}\text { Turizm } \\
\text { Bakanlığı }\end{array}$ & $\begin{array}{c}\text { Api } \\
\text { Terapi } \\
\text { Uzmanı }\end{array}$ & $\begin{array}{l}\text { Ticaret } \\
\text { Odası }\end{array}$ & Valilik & $\begin{array}{l}\text { Büyükşehir } \\
\text { Belediyesi }\end{array}$ & $\begin{array}{l}\text { Illçe } \\
\text { Tarım }\end{array}$ & $\begin{array}{c}\text { il } \\
\text { Tarım }\end{array}$ & $\begin{array}{c}\text { Arıcılar } \\
\text { Birliği }\end{array}$ & TOPLAM \\
\hline \multirow{8}{*}{ 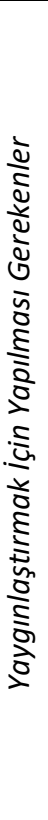 } & $\begin{array}{c}\text { Arı Bahçesi } \\
\text { Kurulması }\end{array}$ & 0 & 0 & 0 & 1 & 1 & 0 & 0 & 0 & 2 \\
\hline & $\begin{array}{c}\text { Profesyonel } \\
\text { Apiterapi } \\
\text { Uygulaması }\end{array}$ & 0 & 1 & 0 & 1 & 1 & 0 & 1 & 1 & 5 \\
\hline & $\begin{array}{c}\text { Tanıtım } \\
\text { Faaliyetlerine } \\
\text { Başlanması }\end{array}$ & 1 & 1 & 0 & 3 & 3 & 1 & 1 & 1 & 11 \\
\hline & $\begin{array}{l}\text { Apiterapi } \\
\text { Merkezleri } \\
\text { Kurulması }\end{array}$ & 0 & 0 & 0 & 1 & 1 & 0 & 1 & 1 & 4 \\
\hline & $\begin{array}{l}\text { Arı Müzesi } \\
\text { Açılması }\end{array}$ & 0 & 0 & 0 & 1 & 1 & 0 & 1 & 1 & 4 \\
\hline & $\begin{array}{c}\text { İl Tarım } \\
\text { Müdürlüğünde } \\
\text { Toplantı }\end{array}$ & 0 & 0 & 0 & 0 & 0 & 0 & 0 & 1 & 1 \\
\hline & $\begin{array}{c}\text { Arıcıları } \\
\text { Bilinçlendirmek }\end{array}$ & 0 & 0 & 1 & 0 & 0 & 1 & 0 & 1 & 3 \\
\hline & TOPLAM & 1 & 2 & 1 & 7 & 7 & 2 & 4 & 6 & 30 \\
\hline
\end{tabular}


A5, A7 ve A11) ve Valilik (A2, A5, A7, A9 ve A11) olduğu bulgulanmıştır.

\section{Tema 3-3 Arıcılık Turizminin Katkıları}

Arı yetiştiricilerine arıcılık turizminin katkıları sorulduğunda verilen cevaplar dört alt başlık oluşturmaktadır. Arıcılık turizminin temelde dört katkısının olabileceği anlaşılmış olup, A7, A8, A10 ve A11 kodlu arıcilar arıcılik turizminin kişilerde ve toplumda bir "çevre bilinci" oluşturarak katkı sağlayabileceğini ifade ederken, A1, A7, A10 ve A11 kodlu arıcilar arıcılık turizminin "topluma da katkı sağlayacağı" görüşündedirler. A2, A5 ve A11 kodlu arıcılar "bölgeye de katk1lari" olabileceği noktasına değinmişlerdir Son olarak "Arı yetiştiricilerine olan katkısı" en fazla tekrar edilen katk1 olup A1, A2, A3, A5, A8, A9, A10 ve A11 kodlu arıcılar bu konuda görüş bildirmişlerdir. Şekil 2'de konuya ilişkin bazı konuşma metinlerine de vurgu yapılarak arıcılık turizminin katkılarına yönelik bulgular model çizilerek açıklanmıştır.

\section{Tema 3-4 Arıcllk Turizminin Boyutları}

Yürütülen bu araştırma kapsamında analiz edilen cevaplar farklı açılardan değerlendirildiğinde "Arıcılık turizminin Boyutları" ve "Karşılaşıla- bilecek Güçlükler" başlıkları altında farklı bakış açılarını ortaya koyan bazı bulgulara da ulaşılmıştır. Bu bulgulara göre geliştirilebilecek arıc1lık turizminin sağlayabileceği yararlardan yola çıkılarak arıcılık turizmi kavramını oluşturan boyutlara dair bilgiler, Tablo 2'de belirtildiği gibidir.

Tablo 2'ye göre arıcılık turizminin "Pazarlama Aracı Olma" boyutu en fazla tekrar edilen boyut olup, arıcılık turizminin en fazla arı yetiştiricilerine katkı sağlayacağ 1 ifadesi ile arasındaki ilişki oldukça güçlüdür. Birçok arıcı tarafından belirtilen diğer bir güçlü ilişki ise arıcılık turizminin çevreye katkı sağlayabileceği mantığından yola çıkılarak "çevre bilinci oluşturma boyutu" arasında ortaya çıkmaktadır.

Araştırmaya katılan arı yetiştiricilerinin verdikleri cevaplar değerlendirildiğinde arıcılık turizmi ve api terapi hakkında bilgi sahibi olduğu anlaşılan iki arıcının görüşleri "Arıcılık Turizminin Katkıları, "Arıcılık Turizminin Boyutları" ve "Arıcılık Turizmini Geliştirmek İçin Yapılması Gerekenler" başlıklarına göre incelendiğinde, Şekil 3'ün orta kısmında var olan oklar her ikisinin de ortak olarak değindiği konuları ifade etmektedir. Bununla birlikte, şeklin dışındaki oklar ise A2 ve A11 numaralı arıcıların aynı konuda-

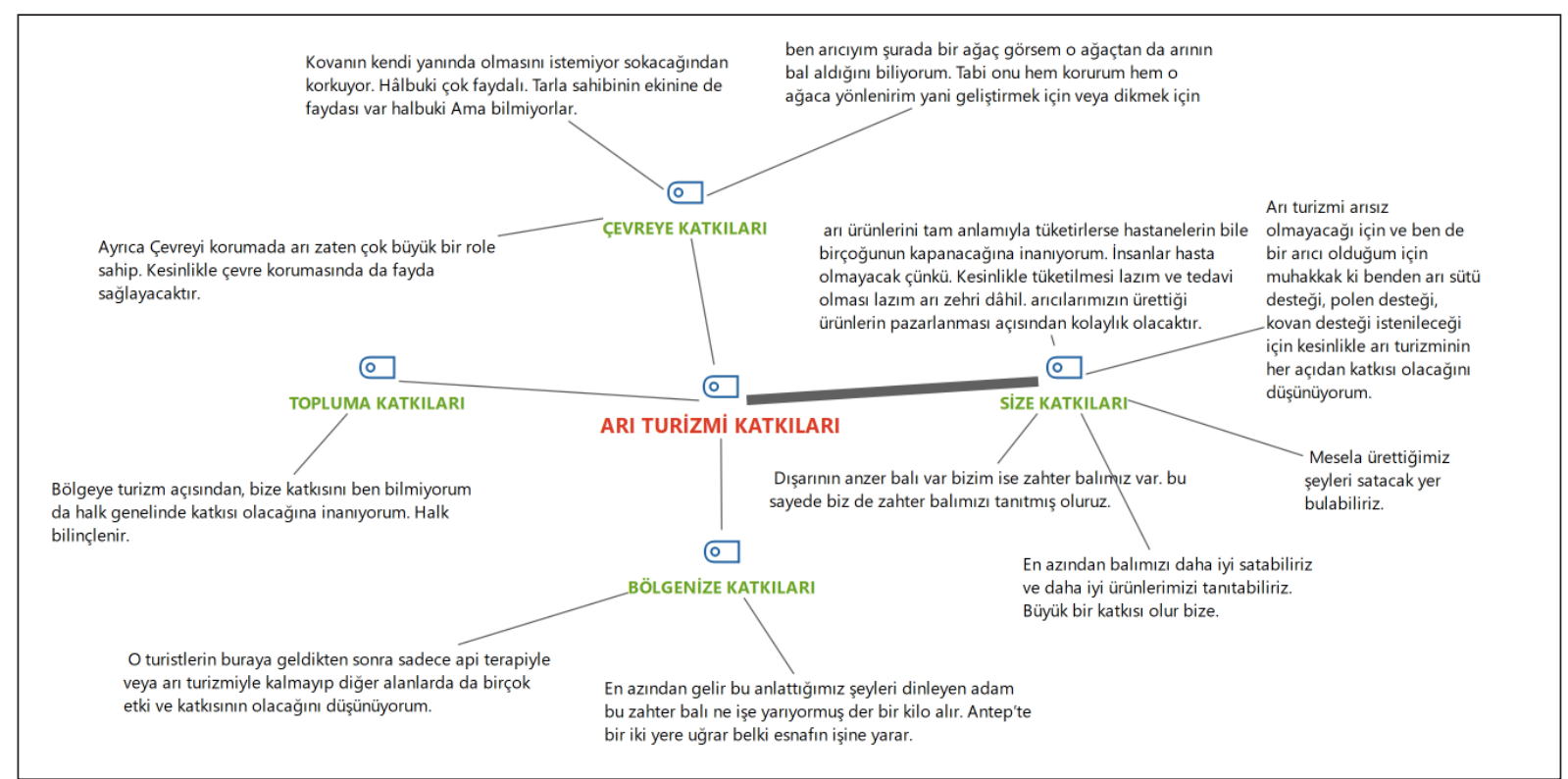

Şekil 2. Arıcılık Turizminin Katkıları Kod-Alt Kod Modeline Ait Bulgular 
Tablo 2. Arıcılık Turizminin Katkısı ve Boyutlarına Göre Kod İlişkiler Tablosu

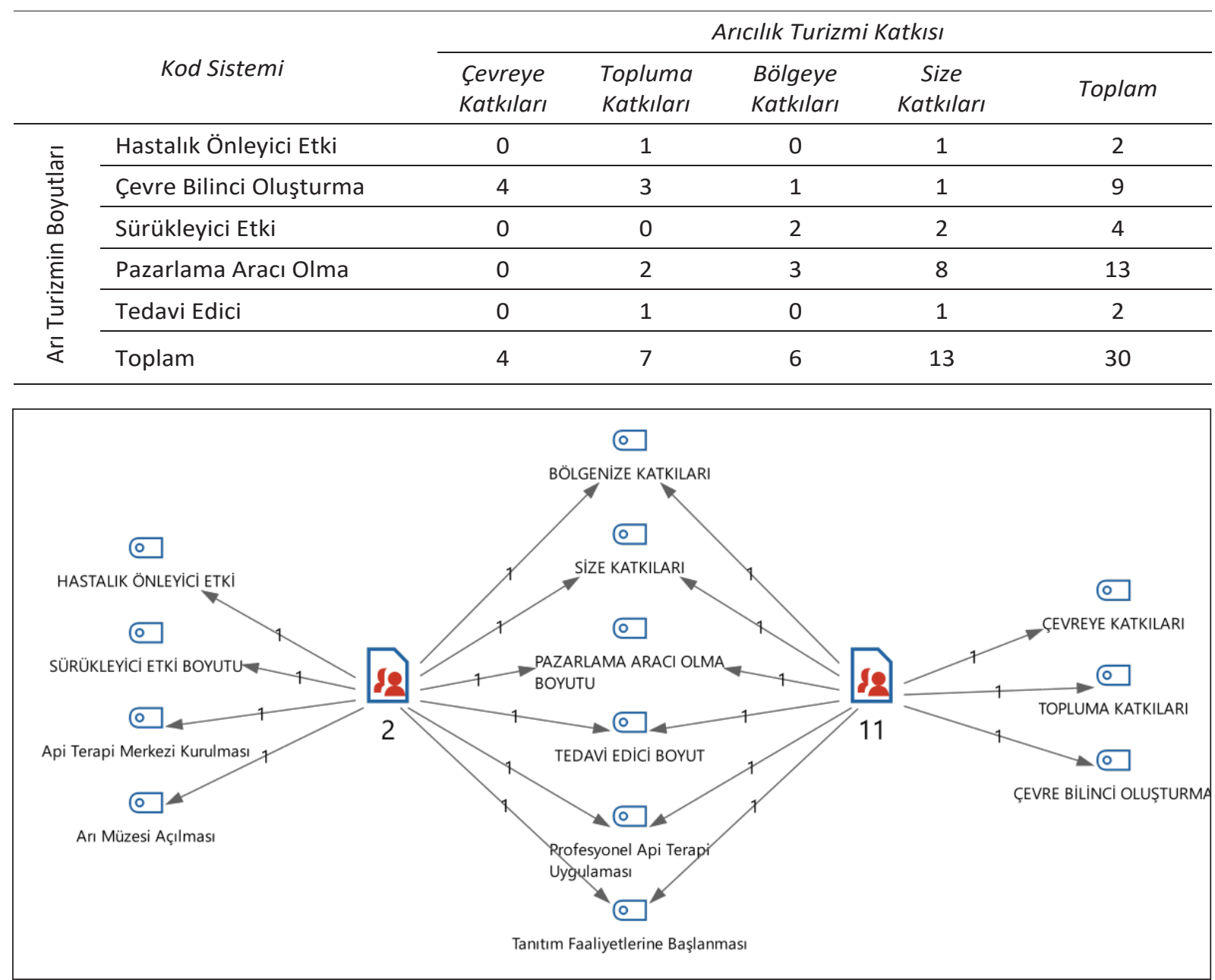

Şekil 3. Arıcı 2 ve Arıcı 11 İki Vaka Modeli

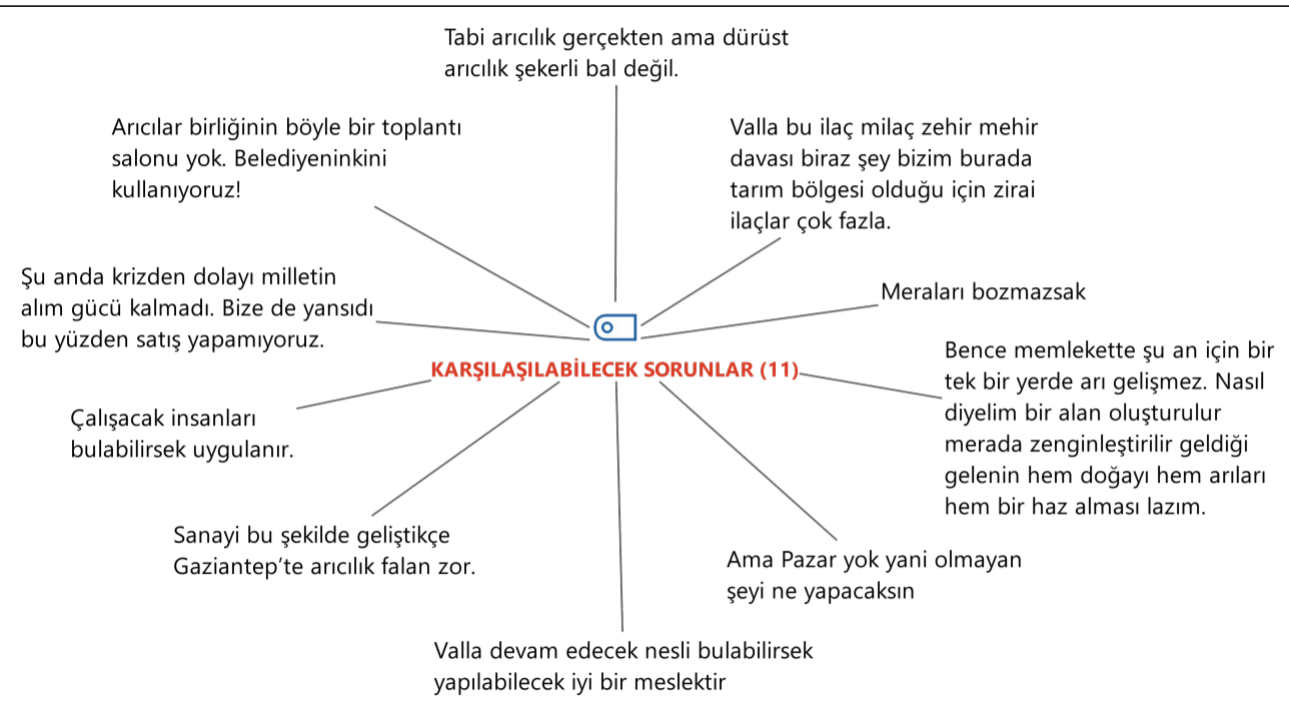

Şekil 4. Arıcılık Turizmi Hayata Geçirilirken Karşılaşılabilecek Sorunlar 
ki farklı görüşlerini yansıtmaktadır. Şekle göre arıcılar; böyle bir arıcılık turizmi ortaya çıkacak olursa, arıcılık turizminin bölgeye katkı sağlayabileceği gibi arı yetiştiricilerine de katkı sağlayacağı konusunda hemfikirdirler. Boyutları ile ilgili beyan ettikleri görüşlere bakıldığında ise arıcılık turizminin arı yetiştiricilerinin kendi ürünlerini tanitarak, pazarlayabilecekleri bir ortam oluşturacağ 1 kanaatindedirler. Bununla birlikte arıcılık turizminin tedavi edici bir boyutu olduğunda da hemfikir oldukları anlaşılmaktadır. Yapılması gerekenler konusunda ise her iki arıcı da Api Terapi Tedavi süreçlerinin profesyonel sağlık uzmanları tarafından yürütülmesi ve tanıtım faaliyetlerinin başlanması gerektiğinde hemfikir oldukları anlaşılmıştır.

\section{Tema 3-4 Karşılaşılabilecek Sorunlar}

Arı yetiştiricilerinin çoğunlukla olumlu baktığ 1 arıcılık turizmine dair sorulan sorular derinlemesine değerlendirildiğinde, arı yetiştiricileri bu süreçte karşılaşılabilecek sorunlar hakkında görüş bildirmişlerdir. Arıcıların ifade ettiği potansiyel sorunlar Şekil 4'te ifade edilmiştir. Bahsi geçen bu konular arı yetiştiriciliğinde karşılaşılan sorunlar ile benzer nitelikte olduğundan farklı bir alt kodlama yapılmamıştır ve katılımcıların ifadeleri değiştirilmeden şekle yansıtılmıştır.

\section{SONUÇ VE ÖNERILER}

Gaziantep'te faaliyet gösteren Gaziantep Arıcılar Birliği'ne kayıtlı arıcıların arıcılık turizmi hakkında bilgi düzeyinin ölçülmesi ve arıcılık turizmi ile ilgili farkındalık oluşturmak amacıyla gerçekleştirilen bu araştırmada arı üreticilerinin büyük çoğunluğunun böyle bir turizm konusunda bilgi sahibi olmadıkları elde edilen sonuçlardan en önemlisi olmuştur. Bunun yanı sıra araştırmaya katılan arıcıların büyük çoğunluğu tedavi tavsiyesinde bulunduklarını da ifade etmişlerdir. Bu durum 2014 yılında yasal bir zemine oturmuş Api Terapi Tedavi yönteminin, uzmanlar tarafından ve yönetmeliğin öngördüğü şekilde hastanelerde ve "konaklama tesislerinde" yürütülmesi gerçeğini gözler önüne sermiştir. Bu durum Suna 2018b'nin çalışmasının sonuçlarıyla paralellik göstermektedir.
Arıcılık turizminin Gaziantep'te ve Türkiye'de uygulanabilirliği konusunda fikir beyan eden arıcılardan birinin fikri bu konu ile ilgili olumsuz olsa da aslında bu fikir yeni bir bakış açısının temelini oluşturmaktadır. Katılımcı, arıcılık turizminin Gaziantep'te hayata geçirilemeyeceğini savunmaktadır. Çünkü kendisi daha fazla verim alabilmek için "arılarını gezdirdiğini" söylemiştir. Arıcılar eğer arılarını mevsimsel özelliklere göre gezdiriyorsa bu durum Türkiye'de arıcılık turizmi için mevsim haritası ortaya çıkarılmasına olumlu yönde etki edecektir. Örneğin, arıcılar Mayıs-Haziran aylarında kovanlarını Güneydoğu Anadolu Bölgesi şehirlerinde tutarken Haziran ayından sonra farklı bitki türlerinin yetiştiği Doğu Anadolu Bölgesi'nin yüksek yaylalarına taşımaktadırlar. Bu durumda arıcılık turizmine katılacak kişiler Mayıs ayında arıcılık turizmine katılacaklarsa Gaziantep'e gelebilirler. Fakat Haziran sonrası bir turizm faaliyetine katılacaklarsa bu durumda Malatya gibi yüksek yaylası olan şehirleri tercih edebileceklerdir.

Arıcıllk turizminin katkılarına ait bulgular değerlendirildiğinde; en fazla katkının arı yetiştiricilerine olacağı sonucuna ulaşılmıştır. Bu durumda arıcilar turistlere hem ürünlerini tanıtma hem de satış imkânı bulabileceklerdir. Arıcıların çoğu ürünlerini satmak hususunda sorun yaşadıklarını mülakat sırasında dile getirmişlerdir.

Arıcılık turizmini geliştirmek için yapılması gerekenler kısmındaki bulgular değerlendirildiğinde; en sık tekrarlanan ifade "tanıtım faaliyetlerine başlanması" olmuştur. Bununla beraber böyle bir turizm türü için Büyükşehir Belediyesi ve Valilik gibi kurumlara bu konuda görev düştüğü sonucuna ulaşılmıştır. Arıcıları bilinçlendirmek bu kapsamda elde edilen bir diğer sonuçtur.

Yerli yazında yeni yeni kavramsal çerçevesini bulan arıcılık turizmi, bu araştırma sonuçlarına göre beş boyut altında yapılandırılabilmektedir. Bu boyutlar "hastalık önleyici etki boyutu", "pazarlama aracı olma boyutu", "sürükleyici etki boyutu" "tedavi edici boyut" ve son olarak "çevre bilinci oluşturma boyutu" olarak adlandırılmıştır. Bu sonuçlar kırsal turizm türünün diğer turizm türleriyle kolay ilişkilendirilebilme (Karacan vd. 2016: 4) özelliğinden yola çıkılarak 
arıcilık turizmi kavramının kirsal turizmin bir alt türü şeklinde yapılandırılabileceği sonucuna ulaşılmasını sağlamaktadır.

Sonuç olarak turist profillerinin çevre bilinci ile yeniden şekil aldığı günümüzde kırsal turizmin alt türleri ön plana çıkarılarak kırsal kalkınma amacına katkı sağlamak gerekmektedir. Bu amaçla Api Terapi Derneği başkanı ile görüşülmeli ve hastaneler dışında yani "konaklama tesislerindeki" api terapi merkezlerinin kurulması sağlanmalıdır. Böylece bu geleneksel ve tamamlayıcı tıp türü, arı yetiştiricileriyle yakın ilişki ve uyum içinde yürütülmüş olacaktır. Aksi taktirde arı ürünleri, alerjisi olan kişiler için tehlikeli durumlar oluşturabileceğinden, yanlış tavsiyenin sonuçları ciddi tehlikelere yol açabilecektir.

Yapılan bu araştırma Gaziantep ili ile sınırlı olup bundan sonraki çalışmalar arıcılık ve bal üretiminin yoğunlukla yapıldığ 1 Ordu, Muğla ve Adana'da gerçekleştirilebilir. Bununla birlikte bu araştırma nitel verilerle tasarlanmış bir yapıdadır, bu konuda çalışacak olan akademisyenler nicel verilerle araştırmaya farklı boyutlar katabileceklerdir. Ayrıca bu alanda çalışmak isteyen araştırmacıların Türkiye'de arıcılık turizminin geliştirilebileceği noktaları belirten bir haritalama sistemi üzerinde yoğunlaşmaları yazına katkı sağlayacaktır.

\section{KAYNAKÇA}

Abou Shaara, H. F. (2014). The Foraging Behaviour of Honeybees, Apis Mellifera: A Review, Veterinarni Medicina, 59 (1): 1-10.

Ayazlar, G. ve Ayazlar, R.A. (2015). Tourism, Environment and Sustainability, Rural Tourism: A Conceptual Approach. Sofya: Kliment Ohridski University Press.

Aydın, O. (2012). AB'de Kırsal Turizmde İlk Beş Ülke ve Türkiye'de Kırsal Turizm, KMÜ Sosyal ve Ekonomik Araştırmalar Dergisi, 14 (23): 39-46.

Bahar, O. ve Yılmaz, E. (2016). Arı Turizmi ve Muğla'da Uygulanabilirliği, Muğla Arıcılık ve Çam Balı Kongresi (ss. 537-538). 1-5 Kasım 2016. Türkiye: Muğla.

Berg, B.L. ve Lune, H. (2015). Sosyal Bilimlerde Nitel Araştırma Yöntemleri. Konya: Pearson Eğitim Yayınevi.

Bhadauria, A ve Rastogi, H. (2012). Rural Tourism: An Avenue for Sustainable Rural Development, International Journal of Multidisciplinary Research, I (8): 2277-9302.

Cabrini, L. (2004). Rural Tourism in Europe: Experiences, Development and Perspectives, European Congress on Rural Tourism (ss. 9-11). 3-5 October 2003, Jaen.
Doğan, S. ve Özaslan, Y. (2017). Kırsal Alan Gelişimi Açısından Kırsal Turizm ve Kırsal Turizmin Dünyadaki Durumu, Erzincan Üniversitesi Sosyal Bilimler Enstitüsü Dergisi, ÖS-IV: 61-78.

Drăgulănescu, I. V. ve Druțu (Ivan), M. (2012). International Journal of Academic Research in Accounting, Finance and Management Sciences, 2 (1): 196-203.

Garau, C. (2015). Perspectives on Cultural and Sustainable Rural Tourism in a Smart Region: The Case Study of Marmilla in Sardinia (Italy), Sustainability, 7: 6412-6434.

Gartner, W. C. (2005). A Perspective on Rural Tourism Development, The Journal of Regional Analysis and Policy, 35 (1): 33-42.

Heneghan, M. (2002). Structures and Processes in Rural Tourism, Rural Development Conference (ss. 72-80). 12 Şubat 2002, İrlanda.

Housam F. ve Abou-Shaara, H. (2015). Suitability of Current and Future Conditions to Apiculture in Egypt Using Geographical Information System, Journal of Agricultural Informatics, 6 (2): 12-22

Karacan, S., Karacan, E. ve Güngör, Y. (2016). Kırsal Turizm ve Alternatif Kırsal Turizm Hizmetleri. 5. Doğu Akdeniz Turizm Sempozyumu (ss. 1-19). 22 Nisan 2016. KKTC.

Kantar, S.ve Svržnjak, K. (2017). Development of Sustainable Rural Tourism, Deturope, 9 (1): 26-34.

Korosec, T.A (2014). Apimondia Working Group: Apimondia and Apitourism, 3rd International Conference of the Beekeeping Associations (ss. 318-319). 20-21 Kasim 2014, Slovenya.

Korosec, T.A (2015). Api-tourism: Transforming Slovenia's Apicultural Traditions into A Unique Travel Experience, WIT Transactions on Ecology and The Environment, Sustainable Development and Planning (VII): 963974.

Korosec, T.A. (2016). Api Turizmi, Api Sağlık, Api Terapi, Muğla Arıcılık ve Çam Balı Kongresi (ss. 112-115). 1-5 Kasim 2016. Türkiye: Muğla.

MAXQDA, (2018). Nitel Araştırmalar Veri Analizi Program1. 2018.2 Version. MQST18-EHLzIN-1iCJza-1P46Z2WpRsUj.

Merriam, S.B. (2015). Nitel Araştırma Desen ve Uygulama için Bir Rehber. Ankara: Nobel Akademik Yayıncılık.

Miles, M.B. ve Huberman, A.M. (1994). Qualitative Data Analysis: A Sourcebook of New Methods. Tousand Oaks, CA: Sage.

Nair, V., Munikrishnan, U. T., Rajaratnam, S. D. ve King N. (2015). Redefining Rural Tourism in Malaysia: A Conceptual Perspective, Asia Pacific Journal of Tourism Research, 20 (3): 314-337.

Neumeier, S. ve Pollermann, K. (2014). Rural Tourism as Promoter of Rural Development-Prospects and Limitations: Case Study Findings from a Pilot Projectpromoting Village Tourism, European Countryside, 6 (4): 270296.

Ongun, U., Gövdere, B. ve Çiçek, U. (2016). Yeşilova'nın Kırsal Turizm Potansiyelinin SWOT Analizi ile Değerlendirilmesi, Süleyman Demirel Üniversitesi Vizyoner Dergisi, 7 (16): 75-88 
Özçatalbaş, O. (2017). Rural Tourism and Development Relations. First International Rural Tourism and Development Congress 16. Ulusal Kırsal Turizm Kongresi (ss. 141-142). 4-6 Mayıs 2017, Bursa.

Pamukçu, H., Aydoğdu, A. ve Gemici, E. (2015). Kırsal Turizm Etkinlikleri Tür ve Sınıflandırılması, Doğu Karadeniz Bölgesi, Sürdürülebilir Turizm Kongresi (ss. 520-528). 14-16 Mayıs 2015, Gümüşhane.

Pantoja, G. Gómez, M., Contreras, C., Grimau, L. ve Montenegro, G. (2017). Determination of Suitable Zones for Apitourism Using Multi-criteria Evaluation in Geographic Information Systems: A Case Study in The O'Higgins Region, Chile, Ciencia e Investigacion Agraria, 44 (2): 139-153.

Resmi Gazete (2014). Geleneksel ve Tamamlayıcı Tıp Uygulamaları Yönetmeliği, http://www.resmigazete.gov.tr/ eskiler/2014/10/20141027-3.htm, (Erişim tarihi: 5 Mayıs 2019).
Shiffler, K. (2014 Api-Tourism as Added-Value: The Case of La Ruta de la Miel in Chile. (Basılmamış Yüksek Lisans Tezi). Norveç: Norwegian University of Life Sciences Faculty of Veterinary Medicine and Biosciences Department of Plant Sciences (IPV).

Suna, B. (2018a). Api Turizm'in Türkiye'deki Yeri ve Önemi, Uludă̆ Arıcilık Dergisi, 18 (1): 28-41.

Suna, B. (2018b). Sağlık Turizmi Açısından Api Turizm Potansiyelinin SWOT Analizi ile Değerlendirilmesi, 19. Ulusal Turizm Kongresi (ss. 235-241).17-21 Ekim 2018, Afyonkarahisar.

Ün, E., Tutar, F., Tutar, E. ve Erkan, Ç. (2012). Ekonomik Kalkınmada Kırsal Turizmin Rolü: Türkiye Örneği, International Conference on Eurasian Economies (ss. 345-351). 11-13 Ekim 2012. Kazakistan: Almaty.

Wos, B. (2014). Api-Tourism in Europe, Journal of Environmental and Tourism Analysis, 2 (1): 66-74.

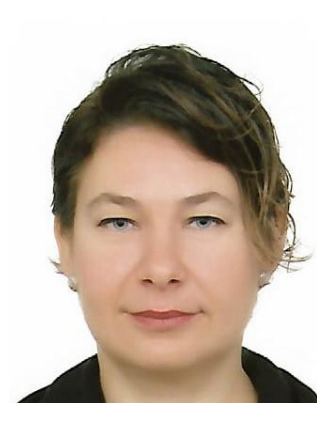

Belma SUNA yer almaktadır.

Uludağ Üniversitesi Turizm ve Otel İşletmeciliği Yüksekokulu'ndan mezun oldu (1996). Yüksek lisans derecesini Gaziantep Üniversitesi'nden İşletme Ana Bilim Dalı'ndan (2009), doktora derecesini Hasan Kalyoncu Üniversitesi'nden Işletme Ana Bilim Dalı'ndan aldı (2017). Gaziantep Üniversitesi'nde Öğretim Görevlisi olarak çalışmaya başladı (2010). Dr. Öğretim Üyesi unvanını aldı (2018). Halen Gaziantep Üniversitesi Turizm ve Otelcilik Meslek Yüksekokulu'nda görev yapmaktadır. Temel çalışma alanları arasında sürdürülebilir turizm, turizm pazarlaması ve gastronomi 